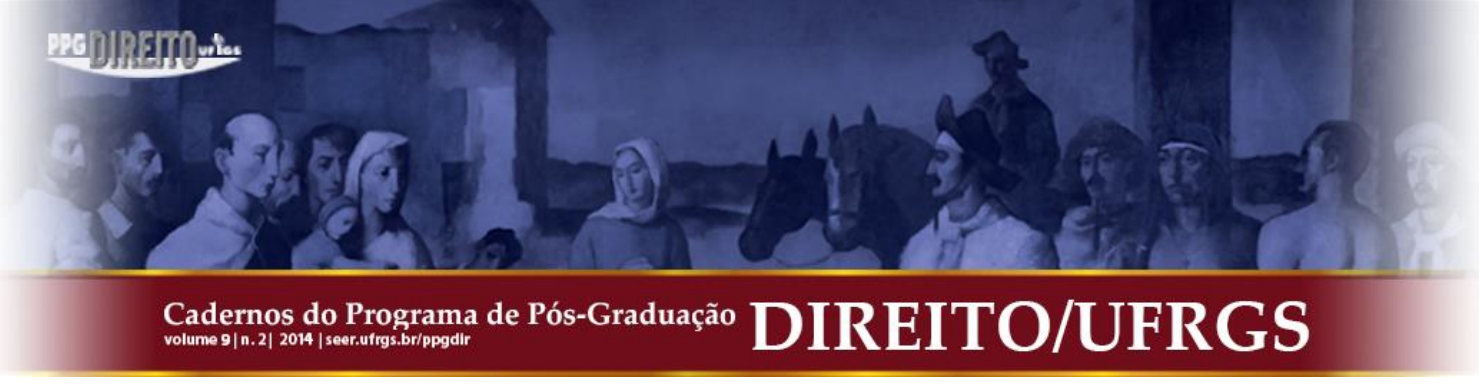

\title{
AMICUS CURIAE E AUDIÊNCIAS PÚBLICAS NO CONTROLE DE CONSTITUCIONALIDADE BRASILEIRO
}

\author{
AMICUS CURIAE AND PUBLIC HEARINGS ON BRAZILIAN CONSTITUTIONAL REVIEW
}

\author{
Oscar Valente Cardoso*
}

\begin{abstract}
RESUMO: O artigo trata de dois institutos inseridos formalmente no controle abstrato de constitucionalidade brasileiro por meio da Lei $\mathrm{n}^{\circ}$ 9.868/99: o amicus curiae e a análise de fatos. A abordagem é ao mesmo tempo teórica, com fundamento em doutrina nacional e estrangeira, e prática, com base na interpretação do Supremo Tribunal Federal. Enfatiza as diferenças existentes entre ambos e a ausência da distinção necessária em determinadas situações. Buscase contribuir para a exata delimitação e aplicação de cada um, além de demonstrar que os dois institutos ampliam os meios processuais à disposição do Supremo Tribunal Federal no exercício de sua função de Tribunal Constitucional, porém, ainda não estão devidamente consolidados na prática da Corte.
\end{abstract}

PALAVRAS-CHAVE: Controle de constitucionalidade; Amicus curiae; Audiências públicas.

\begin{abstract}
This article analyzes two institutes formally added to Brazilian abstract constitutional review through Act $n^{\circ}$ 9.868/99: Amicus Curiae and Fact Review. The approach is at the same time theoretical, based on national and foreign doctrine, and practical, based on the interpretation of the Supreme Federal Court. It emphasizes the differences between themselves and the lack of the necessary distinction in certain situations. It seeks to contribute for defining and implementing both institutes, in addition to demonstrating that the two institutes extend the procedural means available to the Supreme Federal Court in the exercise of its function as Constitutional Court, although they are not yet duly consolidated in the practice of the Court.
\end{abstract}

KEYWORDS: Constitutional review; Amicus curiae; Public hearings.

SUMÁRIO: Introdução. 1. A abertura do processo constitucional. 2. Amicus curiae: origens e definição. 2.1. Histórico legislativo brasileiro. 2.2. Natureza jurídica e delimitação conceitual. 2.3. O amicus curiae no controle abstrato de constitucionalidade. 3. Audiências públicas: aspectos destacados. 4. Amicus curiae e audiências públicas: distinções necessárias. Considerações finais. Referências.

\section{INTRODUÇÃO}

A norma, em regra, retrata uma situação de fato. Logo, o conhecimento dos fatos relevantes considerados na edição do ato normativo auxilia na prestação jurisdicional. Para tanto, dois institutos previstos no controle concentrado ou abstrato de constitucionalidade podem ser utilizados para a percepção dos pressupostos fáticos da norma, o esclarecimento de situações de fatos e das possíveis consequências da manutenção - ou não - da espécie normativa no ordenamento jurídico: o amicus curiae e a análise de fatos.

\footnotetext{
* Doutorando em Direito pela Universidade Federal do Rio Grande do Sul (UFRGS), Mestrado em Direito e Relações Internacionais pela Universidade Federal de Santa Catarina (UFSC), Especialização em Direito Público pela UNIVALI/IJUFE, em Direito Constitucional pela UNISUL, em Direito Processual Civil pela UNISUL, MBA em Comércio Internacional pela FATEC e MBA em Planejamento e Gestão Estratégica pela FACINTER. Juiz Federal na 4a Região (PR/RS/SC), exercendo o cargo de Juiz Auxiliar do Supremo Tribunal Federal (no Gabinete do Ministro Teori Zavascki) e Professor da Escola Superior da Magistratura Federal de Santa Catarina (ESMAFESC).
} 


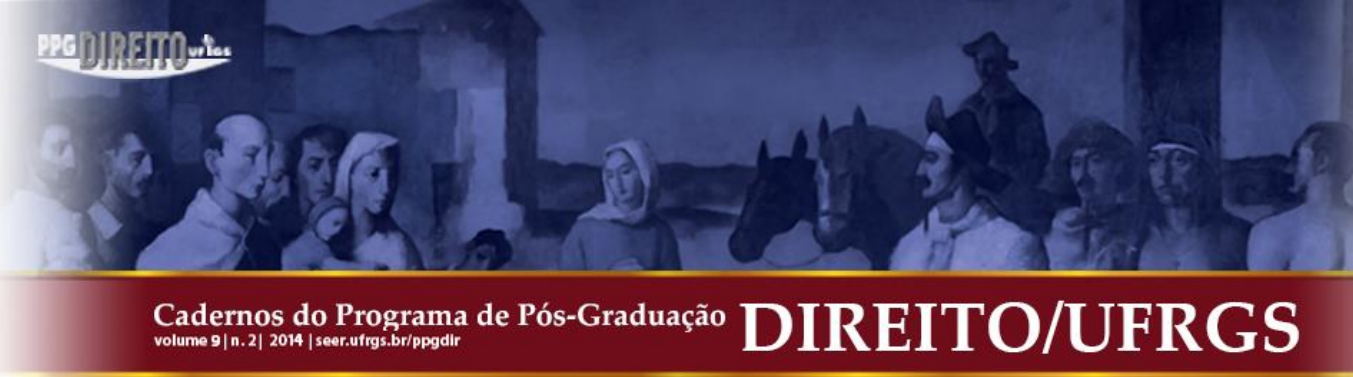

$\mathrm{O}$ artigo analisa o amicus curiae e a análise de fatos no desempenho do controle abstrato de constitucionalidade pelo Supremo Tribunal Federal (STF), destacando suas características e diferenças, por meio de sua reconstrução histórica e do estudo teórico e prático dos institutos.

\section{A ABERTURA DO PROCESSO CONSTITUCIONAL}

Dois entendimentos diferenciados resumem as principais posições existentes a respeito da amplitude do controle de constitucionalidade das normas.

De um lado, sustenta-se que o controle de constitucionalidade é de natureza exclusivamente formal, pois o órgão legitimado para efetuá-lo pode analisar apenas objetivamente a conformidade - ou não - do ato normativo, não lhe competindo verificar, por exemplo, os motivos que levaram à elaboração de uma lei, ou os seus fundamentos ${ }^{1}$. Assim, a exigência de vantagem pessoal pelos parlamentares que votaram pela aprovação da lei não levaria à sua inconstitucionalidade, porque esse seria um fato irrelevante para o controle.

Contudo, por outro lado, defende-se que a jurisdição constitucional não se resume à verificação da compatibilidade das leis e atos normativos em face da Constituição. Afirma-se que houve uma relativização da hermenêutica constitucional, em virtude de sua complexidade e pluralidade. Logo, os juízes e tribunais exercem somente a interpretação jurídica da Constituição, havendo diversos outros intérpretes, principalmente as forças públicas; se, por exemplo, nenhum dos legitimados provoca o STF a exercer o controle concentrado de constitucionalidade, as normas continuam a existir, mesmo que sem uma interpretação judicial $^{2}$. Ainda, para Peter Häberle, quem "vive" o contexto regulado pela norma (ou seja, seu destinatário) é um de seus co-intérpretes, não existindo um monopólio da interpretação, e a principal função de uma Corte Constitucional é a de interpretar a Constituição com base em uma perspectiva atualizada de sua visão pública (HÄBERLE, 1997, p. 13-15 e 41).

Portanto, o ato de interpretar e aplicar a norma não é absolutamente abstraído da realidade, da mesma forma que não é o ato de legislar. Os fatos e as prognoses legislativas consistem na percepção que o legislador tem da realidade, dos eventos (sociais, políticos,

\footnotetext{
${ }^{1}$ Nesse sentido: BURDEAU, HAMON, TROPER, 2005, p. 60.

${ }^{2}$ Com esse entendimento: MENDES, 2006, p. 463-472.
} 


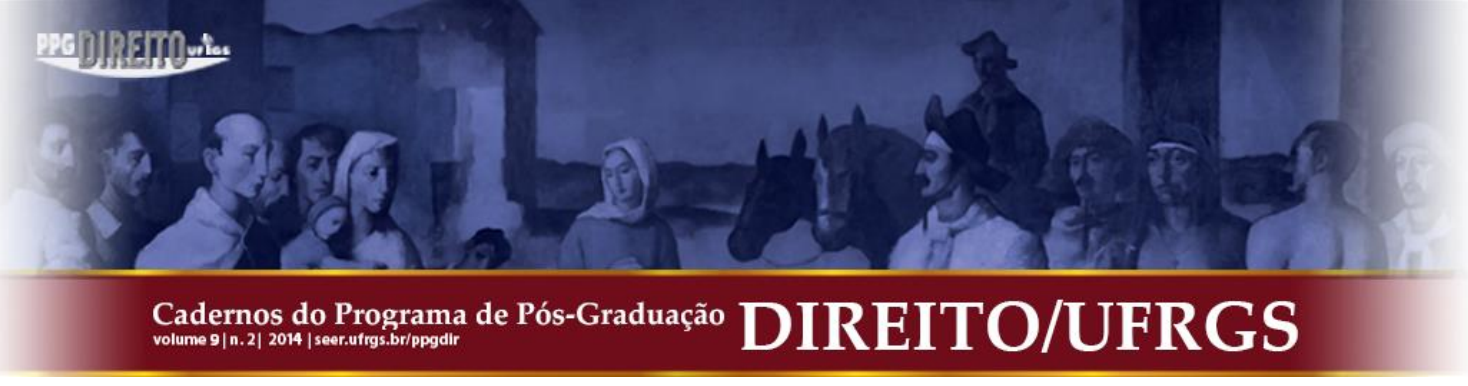

econômicos etc.) que leva em consideração na elaboração de um ato normativo, ou nas presunções ou suposições relativas aos efeitos futuros de uma norma a ser aprovada pelo Legislativo $^{3}$. Em outras palavras, trata-se da inclusão de elementos fáticos na hermenêutica constitucional, não se resumindo às questões de fato, mas abarcando todos os fatos relevantes na elaboração e aplicação da espécie normativa.

Como forma de concretização dessa tendência, dois institutos ganharam força nos últimos 15 anos no Brasil e serão analisados na sequência: o amicus curiae e a análise de fatos.

\section{AMICUS CURIAE: ORIGENS E DEFINIÇÃO}

O "amigo da Corte", ou "amigo da Justiça", tem origens distintas no Direito Romano e no Direito Inglês, e foi desenvolvido principalmente nos Estados Unidos, sendo lá denominado de friend of the Court ${ }^{4}$. Tem origem controversa, pois para alguns doutrinadores deriva do consilliarius do Direito Romano, e para outros provém do Direito penal britânico 5 .

Trata-se de pessoa, em regra, sem relação ou interesse próprio na lide, com a atribuição de opinar ou prestar informações relativas à matéria controvertida, podendo o órgão julgador conferir à sua manifestação o valor que entender adequado. Não se trata de testemunha ou perito, não é remunerada, não exerce a função de fiscal da lei destinada ao Ministério Público, tampouco está sujeita à exceção de suspeição.

\footnotetext{
${ }^{3}$ A Corte Constitucional alemã distingue se o erro de prognóstico pelo legislador ocorreu no início ou se após decorrido certo lapso temporal de aplicação legal: na primeira hipótese o ato normativo é nulo, e na segunda o erro é irrelevante, pois não se pode antever todos os fatores variados e não pretendidos que podem vir a surgir (MENDES, 2006, p. 479-480).

${ }^{4}$ Sua participação está prevista na Regra $\mathrm{n}^{\circ} 37$ das Rules of the Supreme Court of the United States, podendo a manifestação do amicus curiae se dar por escrito ou oralmente; é admitido quando levar ao conhecimento da Suprema Corte matéria relevante que não tiver sido arguida pelas partes, devendo ainda ter o consentimento destas; caso contrário, deve juntar suas razões e a das partes, para que sua admissão - ou não - seja decidida pelo julgador: "Rule 37. Brief for an Amicus Curiae. 1. An amicus curiae brief that brings to the attention of the Court relevant matter not already brought to its attention by the parties may be of considerable help to the Court. An amicus curiae brief that does not serve this purpose burdens the Court, and its filing is not favored. An amicus curiae brief may be filed only by an attorney admitted to practice before this Court as provided in Rule 5. (...)".

${ }^{5}$ Paulo de Tarso Duarte Menezes ressalta que em Roma a participação do consilliarius somente era possível por chamamento do julgador, e devia se manter neutro no litígio; de outro lado, sua origem na Inglaterra é mais aproximada das características atuais, com liberdade para o magistrado admitir a manifestação dos amici curiae, que abrangia discussões acerca de leis e precedentes dos Tribunais (MENEZES, 2007, p. 36-37). Para Damares Medina, "o traço original do amicus curiae ainda está presente em várias definições atuais, que o identificam como um terceiro que não possui um interesse direto na solução da controvérsia" (MEDINA, 2010, p. 37). Ainda a respeito dos antecedentes históricos: BAZÁN, 2005, p. 31-33. Da mesma forma: BUENO, 2012, p. 143-333.
} 


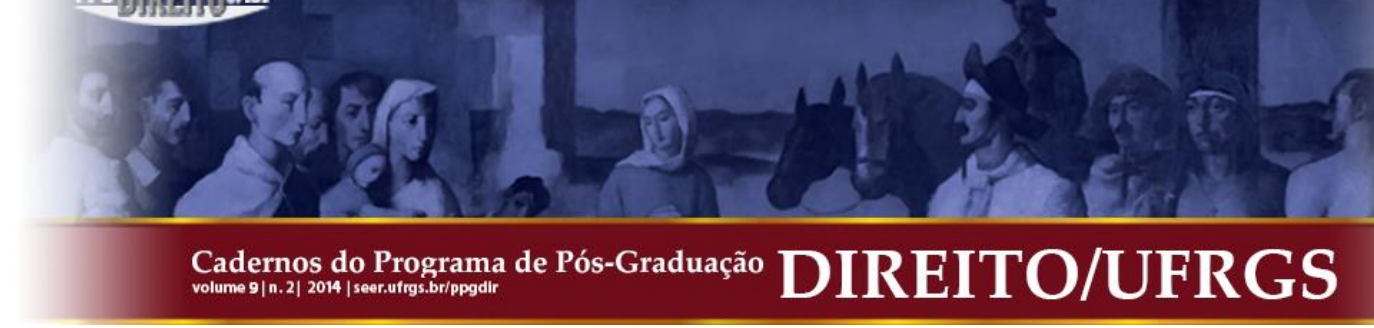

\subsection{Histórico Legislativo Brasileiro}

No Brasil, diversos atos normativos admitem a sua presença. O primeiro dispositivo legal a prever o amicus curiae foi o art. 31 da Lei $\mathrm{n}^{\circ}$ 6.385/76 (com a redação incluída pela Lei $n^{\circ}$ 6.616/78), segundo o qual, nos processos quem envolvam matéria incluída nas atribuições da Comissão de Valores Mobiliários (CVM), esta deve ser intimada para, querendo, oferecer parecer ou prestar esclarecimentos, em quinze dias a contar da intimação. Prestando esclarecimentos, a CVM deve ser intimada de todos os atos subsequentes, e possui legitimidade recursal, quando não houver recurso interposto pelas partes (art. $31, \S \S 2^{\circ}$ e $3^{\circ}$ ).

A Lei $\mathrm{n}^{\circ}$ 8.884/94 previa em seu art. 89 que "nos processos judiciais em que se discuta a aplicação desta lei, o Cade deverá ser intimado para, querendo, intervir no feito na qualidade de assistente". Verifica-se semelhança com o dispositivo referente à CVM, pois admite somente uma entidade (o Conselho Administrativo de Defesa Econômica - CADE) como amicus curiae, sua manifestação é obrigatória ("será esta sempre intimada" e "deverá ser intimado"), e estritamente nos processos judiciais que tenham entre seu objeto matéria afeta aos amici curiae. Apesar de a lei qualificá-lo como assistente, considerando que o CADE não busca proteger o interesse de umas das partes, visando apenas a observância da lei e dos princípios constitucionais da ordem econômica, é doutrinariamente tratado como amigo da Corte $^{6}$. A regra foi mantida pela Lei $\mathrm{n}^{\circ} 12.529 / 2011$ (que revogou a Lei $\mathrm{n}^{\circ} 8.884 / 94$ ), em seu art. 118: "Nos processos judiciais em que se discuta a aplicação desta Lei, o Cade deverá ser intimado para, querendo, intervir no feito na qualidade de assistente".

Ainda, a Lei $n^{\circ} 9.469 / 97$, em seu art. $5^{\circ}$, parágrafo único, preceitua que nos processos judiciais cuja decisão possa ter reflexos (diretos ou indiretos) de natureza econômica, as pessoas jurídicas de direito público podem intervir, independentemente da demonstração de interesse jurídico, para esclarecer questões de fato e de direito. Essa participação abrange a juntada de documentos e memoriais considerados úteis ao exame do assunto discutido. Ainda, possuem legitimidade recursal, hipótese em que são consideradas partes, para verificação e eventual deslocamento de competência. Trata-se de hipótese que gera polêmica na doutrina,

\footnotetext{
${ }^{6}$ A respeito do assunto: AGUIAR, 2005, p. 22; FERREIRA, 2008, p. 131.
} 


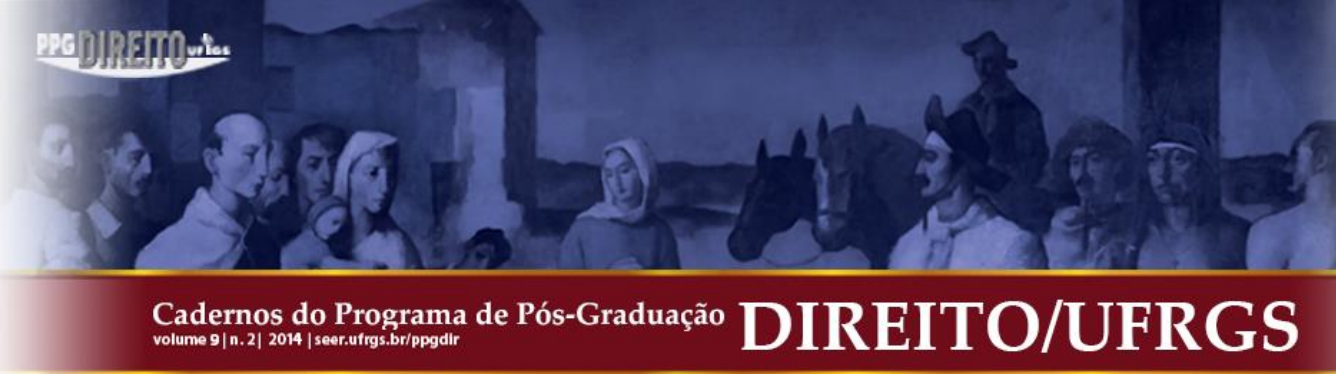

não só quanto à caracterização - ou não - do amicus curiae ${ }^{7}$, mas por permitir que a União, autarquias, fundações públicas, sociedades de economia mista e empresas públicas federais possam ingressar em processos judiciais sem que possuam qualquer interesse jurídico.

No processo administrativo federal também existe figura similar ao amicus curiae. Apesar de não se referir a órgão jurisdicional, o art. 31 da Lei no 9.784/99 determina que se a matéria abranger assunto de interesse geral, e não havendo prejuízo para a parte interessada, o órgão competente pode, motivadamente, abrir período de consulta pública para a manifestação de terceiros, antes da decisão do pedido.

A Lei $\mathrm{n}^{\circ}$ 10.259/2001, que regulamenta os Juizados Especiais Federais, também possui previsão de participação, em grau recursal, do amicus curiae. Na hipótese em que a orientação da Turma Nacional de Uniformização de Jurisprudência dos Juizados Especiais Federais contrariar súmula ou posição majoritária do Superior Tribunal de Justiça, é cabível o recurso de pedido de uniformização ao STJ. Em seu procedimento, prevê o art. 14, § $7^{\circ}$, que “(...) o relator pedirá informações ao Presidente da Turma Recursal ou Coordenador da Turma de Uniformização e ouvirá o Ministério Público, no prazo de cinco dias. Eventuais interessados, ainda que não sejam partes no processo, poderão se manifestar, no prazo de trinta dias"8. $\mathrm{O}$ Ministério Público, o Presidente da Turma Recursal e o Coordenador da Turma de Uniformização prestam informações em virtude de suas funções institucionais, não se confundindo com o amigo da Corte, previsto na parte final do citado dispositivo. A Lei $\mathrm{n}^{\circ}$ 12.153/2009, que instituiu os Juizados Especiais da Fazenda Pública nos Estados, Distrito Federal e Municípios, reproduz o pedido de uniformização ao STJ, mas não repetiu a possibilidade de manifestação de amigos da Corte, em seu art. 19, § $3^{\text {o: }}$ "Se necessário, o relator pedirá informações ao Presidente da Turma Recursal ou Presidente da Turma de Uniformização e, nos casos previstos em lei, ouvirá o Ministério Público, no prazo de 5 (cinco) dias"9. Apesar de atualmente não haver previsão expressa, o Projeto de Lei $\mathrm{n}^{\circ}$ 4.723/2004 propõe a inclusão dos arts. 50-A a 50-D na Lei n 9.099/95, acerca da uniformização de jurisprudência nos Juizados Especiais Estaduais, sendo que o $\S 4^{\circ}$ do art. 50-B admite a participação dos amici curiae no prazo de 30 dias.

\footnotetext{
${ }^{7}$ Com o entendimento de se tratar de hipótese de admissão de amigo da Corte: PEREIRA, 2002, p. 85.

${ }^{8}$ Essa regra também incide sobre o recurso extraordinário para o STF (art. 15 da Lei $\mathrm{n}^{\circ}$ 10.259/2001).

${ }^{9} \mathrm{O}$ sistema recursal dos Juizados Especiais da Fazenda Pública é analisado no capítulo 12 de: CARDOSO, 2010.
} 


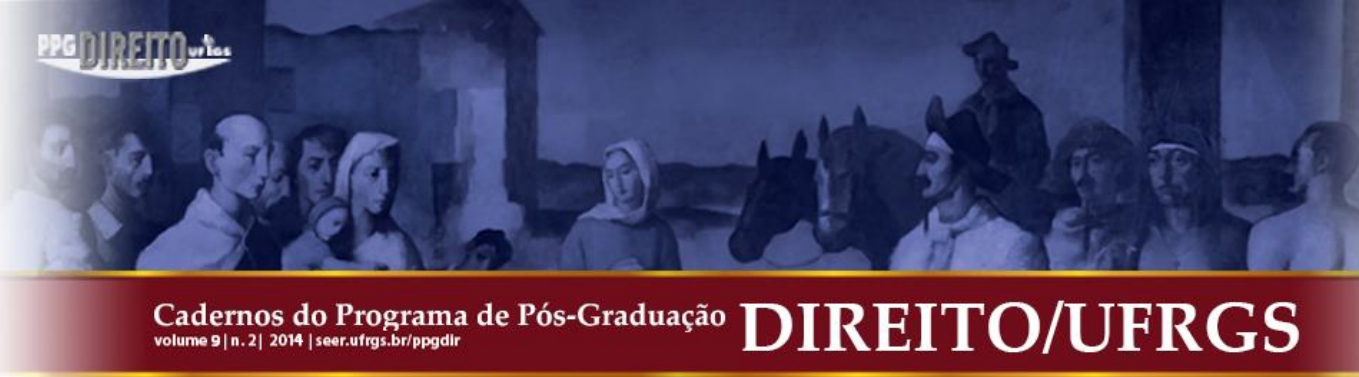

$\mathrm{O} \S 2^{\circ}$ do art. $3^{\circ}$ da Lei ${ }^{\circ} 11.417 / 2006$ prevê hipótese de atuação dos amigos da Corte nos procedimentos de edição, revisão ou cancelamento de enunciado da súmula vinculante ${ }^{10}$.

Igualmente, a Lei n ${ }^{\circ}$ 11.418/2006 acrescentou o art. 543-A ao Código de Processo Civil, que em seu $\S 6^{\circ}$ admite a manifestação de amicus curiae na análise da repercussão geral em recurso extraordinário pelo $\mathrm{STF}^{11}$.

A Lei $n^{\circ} 11.672 / 2008$ acrescentou ao CPC o art. 543-C, com o procedimento a ser seguido no julgamento de recursos repetitivos pelo STJ, o qual permite, em seu $\S 4^{\circ}$, a atuação de amici curiae ${ }^{12}$.

Verifica-se não existir uma definição ou delimitação legal, tampouco uniformização na atuação dos amici curiae no direito brasileiro, sendo obrigatória em algumas normas, facultativa em outras, limitada a somente um órgão em umas leis, a pessoas jurídicas em outras e sem restrição em algumas, e com liberdade de manifestação igualmente diferenciada para cada ato normativo que o regulamenta. Ainda, as normas legais restringem-se a prever a sua manifestação em processos judiciais (com uma hipótese em processo administrativo), em determinadas situações, não existindo no Brasil uma regulamentação ampla. Essa lacuna dá margem a controvérsias, equívocos com outros institutos e obstáculos à sua efetiva participação processual.

\subsection{Natureza Jurídica e Delimitação Conceitual}

A natureza jurídica e processual do amigo da Corte é controvertida, havendo quem sustente ser terceiro, assistente, terceiro ou assistente atípicos (qualificados por requisito de admissibilidade), auxiliar da justiça, colaborador informal, forma especial de intervenção, ou uma espécie de participação da sociedade (por meio de uma entidade representativa) no controle abstrato de constitucionalidade ${ }^{13}$. Afirma-se ainda que possui um interesse

\footnotetext{
10 “\$ $2^{\circ}$ No procedimento de edição, revisão ou cancelamento de enunciado da súmula vinculante, o relator poderá admitir, por decisão irrecorrível, a manifestação de terceiros na questão, nos termos do Regimento Interno do Supremo Tribunal Federal".

11 “ $\S 6^{\circ}$ O Relator poderá admitir, na análise da repercussão geral, a manifestação de terceiros, subscrita por procurador habilitado, nos termos do Regimento Interno do Supremo Tribunal Federal".

12 "O relator, conforme dispuser o regimento interno do Superior Tribunal de Justiça e considerando a relevância da matéria, poderá admitir manifestação de pessoas, órgãos ou entidades com interesse na controvérsia”.

${ }^{13}$ A respeito da controvérsia acerca da natureza jurídica do instituto: KÖHLER, 2010, p. 4-8. Conforme já se decidiu no STF: “(...) A sua atuação nesta via processual 'como colaborador informal da Corte' não configura,
} 


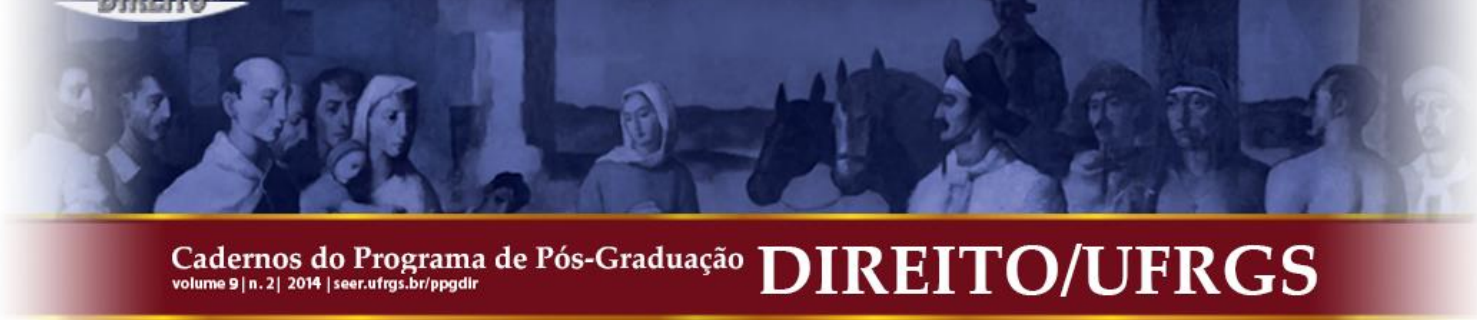

Preliminarmente, o Tribunal, por maioria, resolvendo questão de ordem suscitada no julgamento das ações diretas acima mencionadas, admitiu, excepcionalmente, a possibilidade de realização de sustentação oral por terceiros admitidos no processo abstrato de constitucionalidade, na qualidade de amicus curiae. Os Ministros Celso de Mello e Carlos Britto, em seus votos, ressaltaram que o $\S 2^{\circ}$ do art. $7^{\circ}$ da Lei 9.868/99, ao admitir a manifestação de terceiros no processo objetivo de constitucionalidade, não limita a atuação destes à mera apresentação de memoriais, mas abrange o exercício da sustentação oral, cuja relevância consiste na abertura do processo de fiscalização concentrada de constitucionalidade; na garantia de maior efetividade e legitimidade às decisões da Corte, além de valorizar o sentido democrático dessa participação processual. O Min. Sepúlveda Pertence, de outra parte, considerando que a Lei 9.868/99 não regulou a questão relativa a sustentação oral pelos amici curiae, entendeu que compete ao Tribunal decidir a respeito, através de norma regimental, razão por que, excepcionalmente e apenas no caso concreto, admitiu a sustentação oral. Vencidos os Ministros Carlos Velloso e Ellen Gracie, que, salientando que a admissão da sustentação oral nessas hipóteses poderia implicar a inviabilidade de funcionamento da Corte, pelo eventual excesso de intervenções, entendiam possível apenas a manifestação escrita $(. . .)^{20}$.

Com o entendimento contrário, a Corte Especial do Superior Tribunal de Justiça, ao decidir Questão de Ordem no Recurso Especial 1205946/SP, no dia 17/08/2011, resolveu que o amicus curiae não pode ter todas as garantias processuais das partes, porque com elas não se confunde, motivo pelo qual sua colaboração com a Corte deve se dar somente por escrito, e não oralmente ${ }^{21}$.

\subsection{O Amicus Curiae no Controle Abstrato de Constitucionalidade}

A participação do amigo da Corte no controle abstrato de constitucionalidade está prevista no art. $7^{\circ}, \S 2^{\circ}$, da Lei $n^{\circ}$ 9.868/99: “o relator, considerando a relevância da matéria e

\footnotetext{
${ }^{20}$ Em sessão de julgamento do dia 08/02/2007, em questão de ordem no RE 415454, o Min. Gilmar Mendes, relator do processo, reabriu a discussão e admitiu a manifestação verbal pleiteada por amici curiae. Em suas palavras: "Em síntese, creio que o instrumento de admissão de amici curiae confere ao processo de fiscalização de constitucionalidade um colorido diferenciado, emprestando-lhe caráter pluralista e aberto que, a meu ver, não pode ficar restrito ao controle concentrado. Pelo contrário, penso que, justamente por se tratar de matéria ínsita ao modelo dos juizados especiais, a jurisdição constitucional exercida por este Tribunal deve se afastar de uma perspectiva estritamente subjetiva do recurso extraordinário". Seguiram seu entendimento os Ministros Carlos Britto, Carlos Velloso, Sepúlveda Pertence e Ellen Gracie. Por outro lado, votaram pela não manifestação dos amici curiae os Ministros Marco Aurélio, Eros Grau e Cezar Peluso. Ou seja, permitiu-se a manifestação oral dos amigos da Corte por $5 \times 3$ votos, do que se pode extrair que, apesar de a posição ter sido mantida, continua gerando polêmica no Supremo Tribunal Federal, e ainda não está definitivamente resolvida.

${ }^{21}$ Nas palavras do Ministro Teori Zavascki, "nós não temos previsão de sustentação oral por parte de amicus curiae. Ele não pode ser identificado com qualquer uma das partes. Quem chama o amicus curiae é a Corte. Ela chama e pode se satisfazer com a manifestação escrita. Eu acho que não existe uma prerrogativa do amicus curiae de exigir a sustentação oral". Esse foi o voto de oito Ministros do STJ, contra o voto dos outros sete Ministros. Similarmente aos debates no STF, a diferença de apenas um voto demonstra que o tema é controverso e também não se pode afirmar que essa decisão resolveu e uniformizou definitivamente o assunto no STJ.
} 


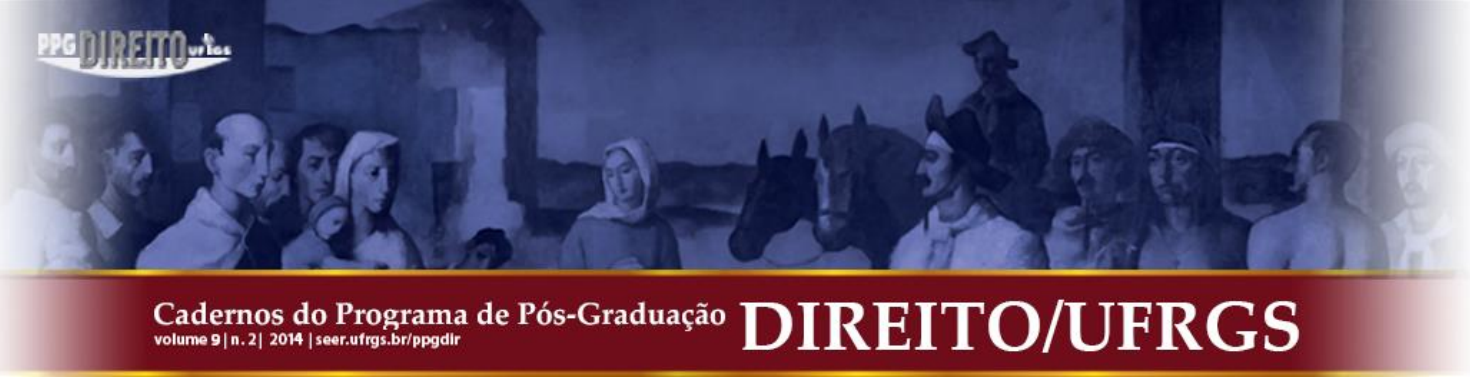

a representatividade dos postulantes, poderá, por despacho irrecorrível, admitir, observado o prazo fixado no parágrafo anterior, a manifestação de outros órgãos ou entidades".

Mesmo anteriormente à previsão legal, o STF já admitia a participação de amici curiae em tais processos. Isso ocorreu, por exemplo, na ADI 748:

AÇÃO DIRETA DE INCONSTITUCIONALIDADE - INTERVENÇÃO ASSISTENCIAL - IMPOSSIBILIDADE - ATO JUDICIAL QUE DETERMINA A JUNTADA, POR LINHA, DE PECAS DOCUMENTAIS - DESPACHO DE MERO EXPEDIENTE IRRECORRIBILIDADE - AGRAVO REGIMENTAL NÃO CONHECIDO.

- O processo de controle normativo abstrato instaurado perante o Supremo Tribunal Federal não admite a intervenção assistencial de terceiros. Precedentes. Simples juntada, por linha, de peças documentais apresentadas por órgão estatal que, sem integrar a relação processual, agiu, em sede de ação direta de inconstitucionalidade, como colaborador informal da Corte (amicus curiae): situação que não configura, tecnicamente, hipótese de intervenção ad coadjuvandum.

- Os despachos de mero expediente - como aqueles que ordenam juntada, por linha, de simples memorial expositivo -, por não se revestirem de qualquer conteúdo decisório, não são passiveis de impugnação mediante agravo regimental (CPC, art. 504) (ADI-AgR 748/RS, Pleno, rel. Min. Celso de Mello, j. 01/08/1994, DJ 18/11/1994, p. 31392)22.

Ainda, o $\S 3^{\circ}$ do art. 482 do Código de Processo Civil, (incluído pela Lei $n^{\circ}$ 9.868/99), que versa a respeito da declaração de inconstitucionalidade nos Tribunais, possui redação semelhante ao do citado art. $7^{\circ}, \S 2^{\circ}$, desta lei, igualmente admitindo a participação do amicus curiae no controle difuso de constitucionalidade: "O relator, considerando a relevância da matéria e a representatividade dos postulantes, poderá admitir, por despacho irrecorrível, a manifestação de outros órgãos ou entidades".

Apesar do veto ao $\S 2^{\circ}$ do art. 18 da Lei $n^{\circ}$ 9.868/99, o STF também aceita a manifestação dos amici curiae na $\mathrm{ADC}^{23}$ e na $\mathrm{ADPF}^{24}$, com base na aplicação analógica e interpretação sistemática da lei ${ }^{25}$.

\footnotetext{
${ }^{22}$ Tratava-se de ADI proposta por Governador de Estado contra decreto legislativo que suspendia a eficácia de decreto estadual, e o Ministro relator aceitou as informações técnicas voluntariamente enviadas pela Comissão de Constituição e Justiça da Assembleia Legislativa do Estado como manifestação de amigo da Corte.

${ }^{23}$ ADC-MC 12/DF, Pleno, rel. Min. Carlos Britto, j. 16/02/2006, DJ 01/09/2006, p. 15.

${ }^{24}$ ADPF 33/PA, Pleno, rel. Min. Gilmar Mendes, j. 07/12/2005, DJ 27/10/2006, p. 31.

${ }^{25}$ A Mensagem n $n^{\circ} 1.674 / 99$, do Presidente da República, contém as razões do veto: "O veto ao $\S 2^{\circ}$ constitui consequência do veto ao $\S 1^{\circ}$. Resta assegurada, todavia, a possibilidade de o Supremo Tribunal Federal, por meio de interpretação sistemática, admitir no processo da ação declaratória a abertura processual prevista para a ação direta no $\S 2^{\circ}$ do art. $7^{\circ}$. Cabe observar que o veto a esses dispositivos repercute na compreensão dos arts. 19 e 20, na parte em que enunciam, respectivamente, 'Decorrido o prazo do artigo anterior' e 'Vencido o prazo do artigo anterior'. Entretanto, eventual dúvida poderá ser superada contando-se o prazo de manifestação do Procurador-Geral da República a partir de despacho do relator determinando a abertura de vista".
} 


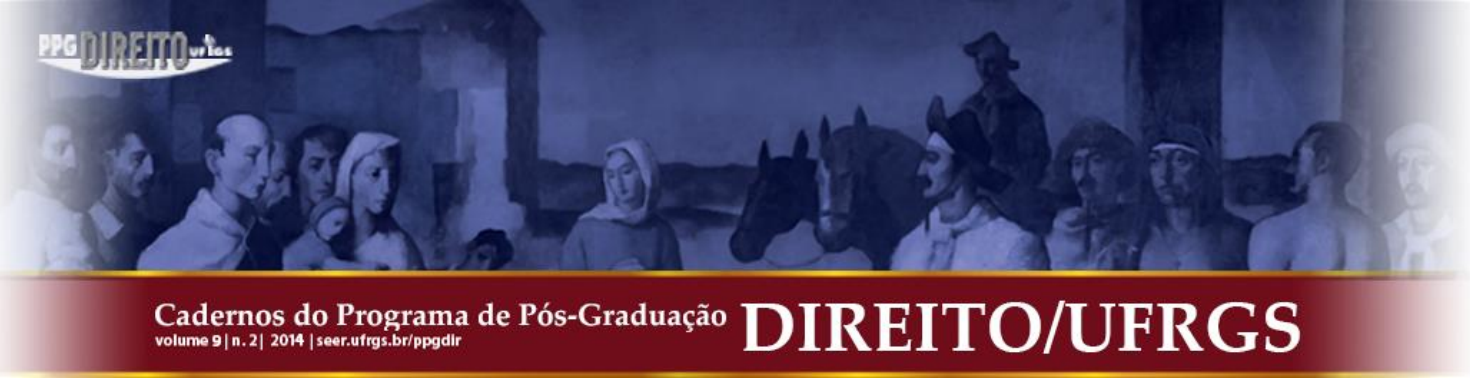

Logo, o ingresso no feito pode ocorrer por decisão do Ministro relator ou a pedido do órgão ou entidade, sujeito à aprovação por parte daquele. A decisão do relator, admitindo ou não o amicus curiae, não é impugnável por recurso, inexistindo meio legal para órgão colegiado do STF aceitá-lo. Nesse sentido:

\begin{abstract}
DECISÃO TERCEIRO - ADMISSIBILIDADE - RECUSA - IRRECORRIBILIDADE.
1. Eis as informações prestadas pelo Gabinete: ADEF - Associação de Desenvolvimento da Família - interpõe agravo regimental contra a decisão - cópia em anexo - proferida por Vossa Excelência, na qual indeferiu a respectiva intervenção, como amicus curiae, no processo em referência. Consigno a publicação da mencionada decisão no dia 30 de agosto deste ano e protocolização do recurso em 8 do mês em curso.

2. A decisão atacada versa sobre a aplicação, por analogia, da Lei ${ }^{\circ} 9.868 / 99$, que disciplina também processo objetivo - ação direta de inconstitucionalidade e ação declaratória de constitucionalidade. Conforme consignado, a admissão de terceiro não implica o reconhecimento de direito subjetivo a tanto. Fica a critério do relator, caso entenda oportuno. Na própria decisão agravada, restou esclarecido que o ato do relator mediante o qual admite, ou não, a intervenção não é passível de impugnação na via recursal - artigo $7^{\circ}, \S 2^{\circ}$, da Lei $n^{\circ} 9.868 / 99$.

3. Ante o quadro, nego seguimento ao agravo, cuja peça deverá ser devolvida à agravante. (...) (ADPF 54 AgR/DF, decisão monocrática, rel. Min. Marco Aurélio, j. 10/09/2004, DJ $01 / 10 / 2004$, p. 39$)^{26}$.
\end{abstract}

Apesar da inexistência de previsão legal, há quem sustente que o amicus curiae tem legitimidade para recorrer da decisão que indefere sua participação no processo, com fundamento em uma interpretação gramatical do art. $7^{\circ}, \S 2^{\circ}$, da Lei $n^{\circ} 9.868 / 99$, segundo o qual é irrecorrível apenas a decisão que deferir a manifestação. Nesse sentido, há precedentes no STF mencionando a possibilidade de interposição de agravo regimental contra a decisão de indeferimento:

AÇÃO DIRETA DE INCONSTITUCIONALIDADE. EMBARGOS DE DECLARAÇÃO OPOSTOS POR AMICUS CURIAE. AUSÊNCIA DE LEGITIMIDADE. INTERPRETAÇÃO DO $\S 2^{\circ}$ DA LEI N. 9.868/99. 1. A jurisprudência deste Supremo Tribunal é assente quanto ao não-cabimento de recursos interpostos por terceiros estranhos à relação processual nos processos objetivos de controle de constitucionalidade. 2. Exceção apenas para impugnar decisão de não-admissibilidade de sua intervenção nos autos. 3 .

\footnotetext{
${ }^{26}$ Ainda: “(...) 6.6. A participação de terceiros nos processos objetivos de controle de constitucionalidade é vedada, salvo na qualidade de amicus curiae --- colaboradores que trazem aos autos informações relevantes ou dados técnicos ---, se assim entender necessário o relator. 7. A jurisprudência desta Corte é no sentido de que são incabíveis os recursos interpostos por terceiros, ainda que figurem como amicus curiae. (...)" (ADI 2359 ED/ES, decisão monocrática, rel. Min. Eros Grau, j. 27/08/2007, DJ 31/08/2007, p. 57). Mais recentemente: RE 632238 AgR/PA, Pleno, rel. Min. Dias Toffoli, j. 23/05/2013, DJe 08/08/2013.
} 


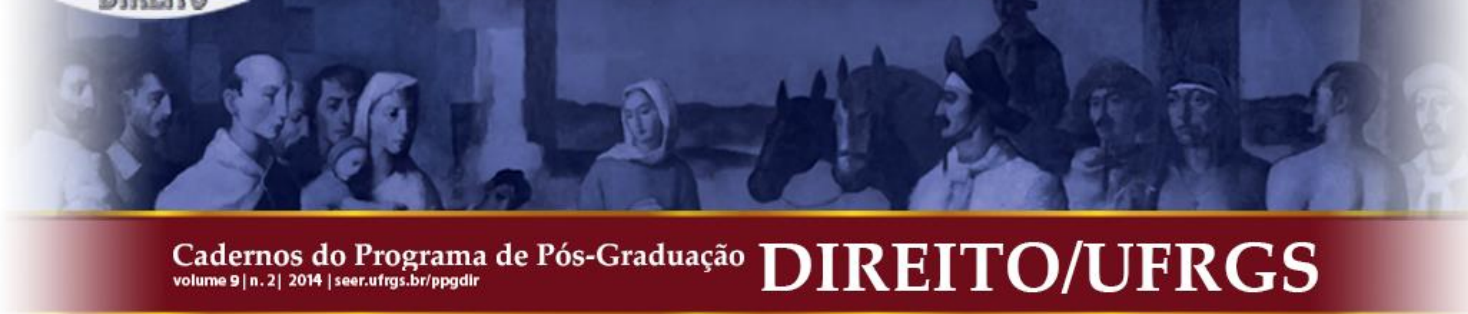

Precedentes. 4. Embargos de declaração não conhecidos (ADI 3615 ED/PB, Pleno, rel. Min. Cármen Lúcia, j. 17/03/2008, DJe 24/04/2008)27.

A sua admissão demanda certos requisitos legais ${ }^{28}$ : (a) subjetivo: somente pode ser pessoa jurídica (órgão ou entidade) ${ }^{29}$; (b) e objetivos: deve possuir representatividade e o processo deve tratar de matéria relevante ${ }^{30}$.

A representatividade é relacionada com a possibilidade de os membros da entidade ser afetados pela decisão do STF no controle concentrado ${ }^{31}$.

${ }^{27}$ No mesmo sentido: “AÇÃO DECLARATÓRIA DE INCONSTITUCIONALIDADE - ADI. Amicus curiae. Recurso. Legitimidade ou legitimação recursal. Inexistência. Embargos de declaração não conhecidos. Interpretação do art. $7^{\circ}$, $\S 2^{\circ}$, da Lei $9.868 / 99$. Amicus curiae não tem legitimidade para recorrer de decisões proferidas em ação declaratória de inconstitucionalidade, salvo da que o não admita como tal no processo" (ADI 3105 ED/DF, Pleno, rel. Min. Cezar Peluso, j. 02/02/2007, DJ 23/02/2007, p. 17).

${ }^{28}$ Há precedente do STF não acatando o Estado como amicus curiae quando a ADI for promovida pelo Governador: “(...) INTERVENÇÃO - GOVERNADOR E ESTADO - CONFUSÃO - INDEFERIMENTO. 1. Eis as informações prestadas pelo Gabinete: O Estado de Santa Catarina requer seja admitido, como amicus curiae, no processo em referência. Registro a conclusão do processo, devidamente instruído, a Vossa Excelência. 2. A regra é não se admitir intervenção de terceiros no processo de ação direta de inconstitucionalidade, iniludivelmente objetivo. A exceção corre à conta de parâmetros reveladores da relevância da matéria e da representatividade do terceiro, quando, então, por decisão irrecorrível, é possível a manifestação de órgãos ou entidades - artigo $7^{\circ}$ da Lei ${ }^{\circ}$ 9.868, de 10 de novembro de 1999. No caso, confundem-se as pessoas natural e jurídica de direito público. A primeira veio a atuar como Chefe do Poder Executivo do Estado e, em nome deste, representando-o, ajuizou a ação. O pedido de intervenção implica verdadeira sobreposição (...)" (ADI 3579/SC, decisão monocrática, rel. Min. Marco Aurélio, j. 12/03/2007, DJ 28/03/2007, p. 15).

${ }^{29} \mathrm{Em}$ decisão monocrática expressa quanto à impossibilidade de pessoa natural atuar como parte ou amicus curiae no controle concentrado: “(...) 9. Aqui, é importante frisar que o autor, à luz do art. 103 da Magna Carta, não detém legitimidade para ingressar, ainda que por via oblíqua ou incidental, nos domínios da referida ação direta, em busca de uma reavaliação do que nela fora decidido em 13.12.2001. Se tal fosse permitido, ter-se-ia de abrir as mesmas portas para qualquer pessoa física que demonstrasse algum interesse no desfecho dela, ação direta. Poderiam manifestar-se os atuais tabeliães e os candidatos inscritos no mencionado concurso, que têm interesses contrapostos. Cada um com sua medida cautelar e seu pedido específico. Ou cada um com sua defesa. Este cenário, pontilhado de situações de caráter individual, alheias à figura do amicus curiae, levaria à descaracterização do controle abstrato. (...)" (AC 688/SP, rel. Min. Carlos Britto, j. 22/03/2005, DJ 01/04/2005, p. 65). Apesar de não poder participar do controle abstrato como amicus curiae, a pessoa natural pode se manifestar com fundamento nos arts. $9^{\circ}$ e 20 , da Lei n ${ }^{\circ} 9.868 / 99$, conforme será visto adiante.

${ }^{30}$ Em uma classificação diferenciada, Guilherme Peña de Moraes divide os requisitos em: (a) materiais, abrangendo a relevância do assunto e a representatividade adequada do autor; (b) e formais, que são o requerimento firmado por profissional habilitado, despacho de mero expediente não sujeito a agravo regimental e observância do prazo de prestação de informações (MORAES, 2006, p. 207).

${ }^{31}$ Baseada no objetivo dos amici curiae de auxiliar o julgamento, Mirella de Carvalho Aguiar sustenta que essa expressão deve ser interpretada em um sentido amplo, envolvendo as noções de autoridade, respeitabilidade, reconhecimento científico e perícia (AGUIAR, 2005, p. 30-31). Para Paulo de Tarso Duarte Menezes, a representatividade deve ser analisada com fundamento nos requisitos exigidos para a pertinência temática dos legitimados para provocar o controle concentrado; desse modo, cumpre esse requisito a entidade que demonstrar que possui interesse institucional específico no tema em discussão (MENEZES, 2007, p. 44-45). Acerca da representatividade, já decidiu o STF: “(...) Como tal, representa categoria econômica cujo interesse no resultado da ação é inconteste, de modo que ostenta adequada representatividade (adequacy of representation), conforme exigido do art. $7^{\circ}, \S 2^{\circ}$, da Lei no 9.868, de 10.11.1999. (...)" (ADI 3225/RJ, decisão monocrática, rel. Min. Cezar Peluso, j. 23/07/2007, DJ 06/08/2007, p. 16). 


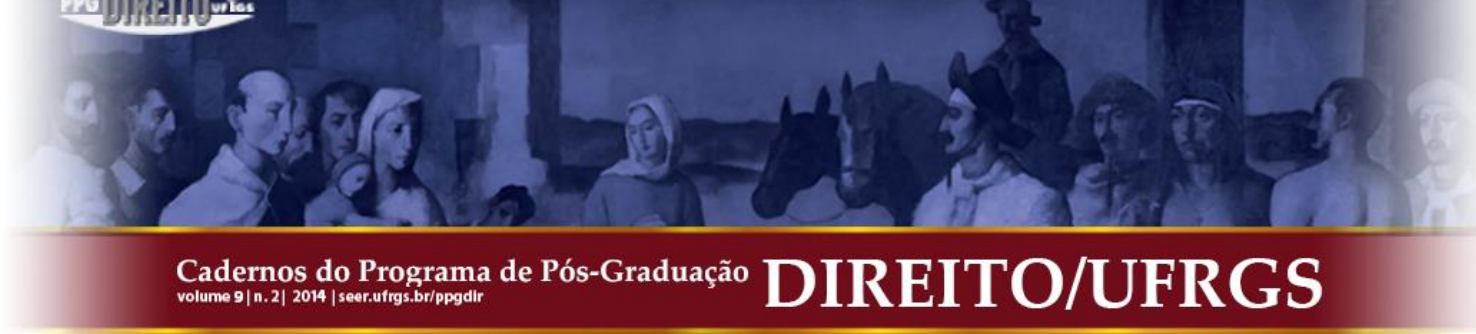

$\mathrm{O}$ vetado $\S 1^{\circ}$ do art. $7^{\circ}$ permitia que os demais legitimados à ADI e ADC pudessem opinar por escrito a respeito do objeto da ação, juntar documentos úteis para o exame do assunto e apresentar memoriais ${ }^{32}$. Existem precedentes do STF admitindo essa participação, com fundamento na possibilidade de manifestação dos amici curiae $^{33}$. Trata-se de um elemento que pode ser desenvolvido para ser utilizado na tênue distinção entre o amicus curiae e os terceiros com interesse subjetivo próprio, mas sua delimitação ainda não foi consolidada no $\mathrm{STF}^{34}$.

Já a relevância da matéria diz respeito à sua complexidade e à extensão dos efeitos da decisão sobre a sociedade, ou sobre parcela considerável desta. Não se confunde com a relevância do processo, tendo em vista que, em princípio, possui importância para o

\footnotetext{
${ }^{32}$ As razões do veto são as seguintes: "A aplicação deste dispositivo poderá importar em prejuízo à celeridade processual. A abertura pretendida pelo preceito ora vetado já é atendida pela disposição contida no $\S 2^{\circ}$ do mesmo artigo. Tendo em vista o volume de processos apreciados pelo STF, afigura-se prudente que o relator estabeleça o grau da abertura, conforme a relevância da matéria e a representatividade dos postulantes. Cabe observar que o veto repercute na compreensão do $\S 2^{\circ}$ do mesmo artigo, na parte em que este enuncia 'observado o prazo fixado no parágrafo anterior’. Entretanto, eventual dúvida poderá ser superada com a utilização do prazo das informações previsto no parágrafo único do art. $6^{\circ}$ ".

33 “(...) Em face do caráter objetivo do processo, é fundamental que não só os representantes de potenciais interessados nos processos que deram origem à ação de descumprimento de preceito fundamental, mas também os legitimados para propor a ação possam exercer direito de manifestação. Independentemente das cautelas que hão de ser tomadas para não inviabilizar o processo, deve-se anotar que tudo recomenda que, tal como na ação direta de inconstitucionalidade e na ação declaratória de constitucionalidade, a arguição de descumprimento de preceito fundamental assuma, igualmente, uma feição pluralista, com a participação de amicus curiae. (...)" (ADPF 97/PA, decisão monocrática, rel. Min. Gilmar Mendes, j. 01/02/2007, DJ 06/02/2007, p. 17).

${ }^{34}$ Quanto à representatividade, o STF reconheceu sua existência em federação estadual de empresas de transportes de passageiros: "1. Deve autorizada a intervenção da Federação das Empresas de Transportes de Passageiros do Estado do Rio de Janeiro - FETRANSPOR, na condição de amicus curiae. Conforme se lhe extrai ao estatuto, a requerente é associação sindical de grau superior, tendo por finalidade 'o estudo, a coordenação, a defesa dos interesses e a representação legal da categoria econômica das transportadoras que operam os serviços municipais e intermunicipais de transportes coletivos de passageiros no Estado do Rio de Janeiro' $\left(\operatorname{art.} 2^{\circ}\right)$. Tem, ainda, por prerrogativa específica 'representar perante o Poder Judiciário acerca dos interesses pertinentes à atividade econômica exercida pelas transportadoras que operam os serviços de transporte coletivo de passageiros' (art. $3^{\circ}$, 'b'). Como tal, representa categoria econômica cujo interesse no resultado da ação é inconteste, de modo que ostenta adequada representatividade (adequacy of representation), conforme exigido do art. $7^{\circ}, \S 2^{\circ}$, da Lei $\mathrm{n}^{\circ} 9.868$, de 10.11.1999. Afinal, é entidade que congrega interesses das empresas de transporte de passageiros, nitidamente capazes de ser atingidos pela decisão da causa (...)" (ADI 3225/RJ, decisão monocrática, rel. Min. Cezar Peluso, j. 23/07/2007, DJ 06/08/2007, p. 16). De outro lado, afastando a representatividade de pessoa natural: "Reginaldo da Luz Ghisolfi requer a sua admissão na presente ação direta de inconstitucionalidade, na qualidade de amicus curiae. Para tanto, alega que há anos vem estudando as questões jurídicas relacionadas à utilização do embrião humano, o que culminou com a elaboração da dissertação de Mestrado intitulada 'A proteção legal do embrião humano e sua relação com a engenharia genética na União Europeia e no Brasil'. Assim resumida a pretensão, passo a decidir. $\mathrm{O} \S 2^{\circ}$ do art. $7^{\circ}$ da Lei ${ }^{\circ}$ 9.868/99 autoriza o relator da ação direta de inconstitucionalidade, considerando a relevância da matéria e a representatividade dos postulantes, a admitir a manifestação de outros órgãos ou entidades. Sucede que esse não é o caso dos autos. Ainda que patente a relevância da matéria aqui veiculada, é incontroversa a falta de representatividade do postulante, razão porque inferido o seu pedido. (...)" (ADI 3510/DF, decisão monocrática, rel. Min. Carlos Britto, j. 03/05/2006, DJ 11/05/2006, p. 6).
} 
ordenamento jurídico toda a ação em que se discute a compatibilidade de ato normativo com a Constituição ${ }^{35}$. Há precedentes no STF aplicando esse requisito quando a própria manifestação do amicus curiae for relevante para o julgamento da causa ${ }^{36}$.

Em regra, o momento para ingressar e se manifestar no feito é no prazo de 30 dias concedido ao órgão que editou o ato normativo questionado para prestar informações (arts. $7^{\circ}$, $\S 2^{\circ}$, e $6^{\circ}$, parágrafo único, da Lei $\left.n^{\circ} 9.868 / 99\right)^{37}$. Contudo, o STF admite a atuação posterior, e em alguns casos até mesmo após o início do julgamento, diante do veto ao $\S 1^{\circ}$ do art. $7^{\circ}$ (ao qual remete o $\S 2^{\circ}$, deixando sem sentido a fixação de prazo), e ressalvando-se que ocorre sem prejuízo dos atos já praticados ${ }^{38}$.

${ }^{35}$ Nesse sentido: AGUIAR, 2005, p. 30; MENEZES, 2007, p. 44-45. Nesse sentido já se decidiu pela ausência de relevância da matéria: “(...) No caso, a simples circunstância de o Sindicato defender os direitos e interesses dos integrantes da categoria, representando-os judicial ou extrajudicialmente - e está em jogo lei local a versar sobre certa parcela remuneratória -, não conduz à admissão no processo objetivo. Indispensável seria haver tema de alta indagação, a exigir o pronunciamento da entidade. 3. Indefiro o pleito. (...)" (ADI 3767/PR, decisão monocrática, rel. Min. Marco Aurélio, j. 06/10/2006, DJ 19/10/2006, p. 47).

36 “(...) No entanto, especialmente diante da relevância do caso ou, ainda, em face da notória contribuição que a manifestação possa trazer para o julgamento da causa, é possível cogitar de hipóteses de admissão de amicus curiae, ainda que fora desse prazo. (...)" (ADI 3538/RS, decisão monocrática, rel. Min. Gilmar Mendes, j. $15 / 12 / 2006$, DJ 01/02/2007, p. 84).

37 "O veto aposto ao $\S 1^{\circ}$ do art. $7^{\circ}$ da Lei federal $\mathrm{n}^{\circ} 9.868$, de 10 de novembro de 1999 , não excluiu a necessidade de observância de prazo prevista no $\S 2^{\circ}$, para admissão dos chamados 'amici curiae'. A inteligência sistemática do disposto no $\S 2^{\circ}$, não podendo levar ao absurdo da admissibilidade ilimitada de intervenções, com graves transtornos ao procedimento, exige seja observado, quando menos por aplicação analógica, o prazo constante do $\S$ único do art. $6^{\circ}$. De modo que, tendo-se exaurido tal prazo, na espécie, aliás pela só apresentação das informações, a qual acarretou preclusão consumativa, já não é lícito admitir a intervenção requerida (...)" (ADI 2997/RJ, decisão monocrática, rel. Min. Cezar Peluso, j. 01/12/2003, DJ 09/12/2003, p. 40).

38 “'(...) No tocante ao momento processual em que é buscada a admissão no feito, aduz que com o veto do texto que se tornaria o art. $7^{\circ}, \S 1^{\circ}$ da Lei $9.868 / 99$, este Supremo Tribunal tem admitido a intervenção dos amici curiae mesmo após o término do prazo para a apresentação das informações, desde que a atuação pretendida ocorra no estágio em que se encontra o processo e sem prejuízo dos atos já praticados. Conclui, assim, que 'seja pela substancial modificação da composição da Corte, seja pela adoção da linha interpretativa no sentido de aplicar ao amicus curiae a regra da assistência', mostra-se razoável o pleito formulado, 'mesmo já tendo sido iniciado o julgamento do feito, que se encontra suspenso em virtude de pedido de vista formulado pelo Exmo. Min. Marco Aurélio'. 3. É certo que esta Corte, na interpretação do art. $7^{\circ}, \S 2^{\circ}$, da Lei 9.868/99, tem destacado a importância de uma maior participação do amicus curiae nos processos de fiscalização abstrata da constitucionalidade dos atos normativos. Conforme asseverou o eminente Ministro Gilmar Mendes em despacho proferido na ADI 3.599 (DJ 22.11.05), 'essa inovação institucional, além de contribuir para a qualidade da prestação jurisdicional, garante novas possibilidades de legitimação dos julgamentos do Tribunal no âmbito de sua tarefa precípua de guarda da Constituição'. Exatamente pelo reconhecimento da alta relevância do papel em exame é que o Supremo Tribunal Federal tem proferido decisões admitindo o ingresso desses atores na causa após o término do prazo das informações (ADI 3.474, rel. Min. Cezar Peluso, DJ 19.10.05), após a inclusão do feito na pauta de julgamento (ADI 2.548, rel. Min. Gilmar Mendes, DJ 24.10.05) e, até mesmo, quando já iniciado o julgamento, para a realização de sustentação oral, logo depois da leitura do relatório, na forma prevista no art. 131, § $3^{\circ}$ do RISTF (ADI 2.777-QO, rel. Min. Cezar Peluso). (...)” (ADI 2588/DF, decisão monocrática, rel. Min. Ellen Gracie, j. 29/11/2005, DJ 05/12/2005, p. 42). Porém, em decisões posteriores foi indeferido o ingresso de amigo da Corte após o início do julgamento: ADI 4067 AgR/DF, Pleno, rel. Min. Joaquim Barbosa, j. 10/03/2010, DJe 22/04/2010. Igualmente: “(...) 4. O amicus curiae somente pode demandar a sua intervenção 
Ainda, o amicus curiae não possui legitimidade para interpor recurso:

(...) 2. Entidades que participam na qualidade de amicus curiae dos processos objetivos de controle de constitucionalidade, não possuem legitimidade para recorrer, ainda que aportem aos autos informações relevantes ou dados técnicos. Decisões monocráticas no mesmo sentido. (...) (ADI-ED 2591/DF, Pleno, rel. Min. Eros Grau, j. 14/12/2006, DJ 13/04/2007, p. 83).

Portanto, o STF entende que o amigo da Corte não tem legitimidade recursal, seja para interpor agravo regimental contra a decisão que indefere sua admissão ou em face da decisão final, seja para apresentar embargos de declaração contra qualquer decisão ${ }^{39}$.

Percebe-se que, na regulamentação constitucional brasileira, o amicus curiae assemelha-se mais a um amicus causae ou amicus partis, por se entender que representa os interesses gerais da coletividade ou de grupos ou classes sociais, constituindo terceiro com interesse na resolução da causa ${ }^{40}$. Logo, não há somente o interesse do STF em demandar a exposição dos amici curiae, mas também destes em apresentar manifestação relativa ao assunto em discussão e as consequências da decisão. Apesar de não se exigir a demonstração de interesse para sua admissão nos processos da ADI, ADC e ADPF, relembra-se que o art. $7^{\circ}, \S 2^{\circ}$, da Lei $n^{\circ} 9.868 / 99$, lista entre os requisitos a existência de representatividade dos postulantes. Consequentemente, existe uma perspectiva potencial de os integrantes do órgão ou entidade serem afetados pela decisão do STF, tanto que se admite a manifestação dos demais legitimados ativos na condição de amici curiae. Justificando essa espécie de interesse, há quem sustente que o amigo da Corte deve se manter neutro na discussão judicial,

até a data em que o Relator liberar o processo para pauta" (ADI 4071 AgR/DF, Pleno, rel. Min. Menezes Direito, j. 22/04/2009, DJe 15/10/2009).

${ }_{39}$ Especificamente a respeito dos embargos declaratórios: “(...) 4. O amicus curie não tem legitimidade para interpor recurso de embargos de declaração. Embargos de declaração opostos pelo Sindifort não conhecidos" (ADI 4167 ED/DF, Pleno, rel. Min. Joaquim Barbosa, j. 27/02/2013, DJe 08/10/2013). Ainda: “(...) - Esta Corte pacificou sua jurisprudência no sentido de que não há legitimidade recursal das entidades que participam dos processos do controle abstrato de constitucionalidade na condição de amicus curiae, 'ainda que aportem aos autos informações relevantes ou dados técnicos' (ADI 2.591-ED/DF, Rel. Min. Eros Grau). II - Precedentes. III - Agravo regimental improvido" (ADI 3934 ED-segundos-AgR/DF, Pleno, rel. Min. Ricardo Lewandowski, j. 24/02/2011, DJe 30/03/2011).

${ }^{40}$ Nesse sentido: AGUIAR, 2005, p. 4. Indo além, Adhemar Ferreira Maciel afirma que essa característica é genérica: "É o caso de amicus curiae do direito norte-americano, que, vez por outra, se traduziria mais num amicus partis ou num amicus causae: o terceiro que comparece ao processo alheio vem, na realidade, mais com o intuito de ajudar uma das partes do que mesmo trazer esclarecimento ao tribunal" (MACIEL, 2002, p. 7). 


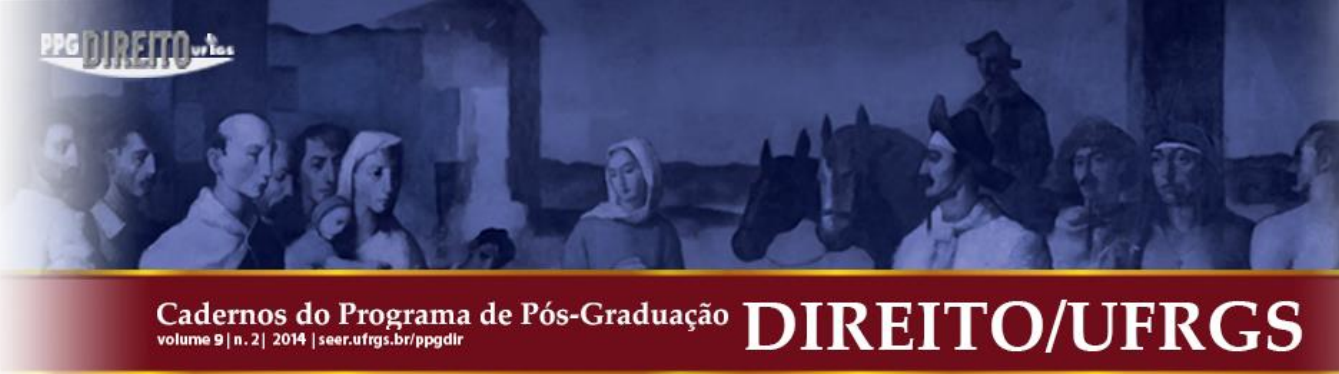

defendendo o interesse da sociedade, e não das $\operatorname{partes}^{41}$. De outro lado, afirma-se que o amicus curiae fortalece a objetividade do controle concentrado, por realçar a participação da sociedade em um processo que interessa a todos, e não somente às partes envolvidas ${ }^{42}$.

Todavia, conforme visto, é inegável que se trata de um terceiro com interesse próprio no julgamento do feito, constituindo outro elemento subjetivo em um processo normalmente abstraído de elementos fáticos. Desse modo, a atuação dos amici curiae no controle abstrato de constitucionalidade, além de exceção à regra que impede a intervenção de terceiros (com ou sem interesse jurídico), também caracteriza importante ressalva à objetividade de tal espécie processual.

\section{Audiências Públicas: Aspectos Destacados}

A interpretação e a aplicação da norma, conforme afirmado inicialmente, não são atos abstraído da realidade. $\mathrm{O}$ ato de legislar também não ignora os fatos, mas, ao inverso, contém a percepção do legislador acerca da realidade, os eventos sociais, políticos e econômicos (entre outros) que leva em conta na elaboração de uma lei.

Com base na doutrina alemã, Gilmar Mendes divide os fatos legislativos em: (a) fatos históricos, aqueles que motivaram as deliberações e escolhas legislativas; (b) fatos atuais, abrangendo investigações empíricas e não-empíricas (estatísticas, consultas à doutrina especializada, opinião de peritos etc.) a respeito de temas contemporâneos à atividade hermenêutica; (c) e eventos futuros (prognoses), nas situações em que a constitucionalidade ou não - do ato normativo necessita da ocorrência de um prognóstico efetuado pelo Legislativo, ou de uma situação que irá ocorrer. Enquanto nas duas primeiras hipóteses o Judiciário analisa como o Legislativo considerou os fatos, na terceira situação é examinado o que o legislador previu (MENDES, 2006, p. 473-475 e 478-479).

A partir dessa classificação, há quem afirme que, quando for demonstrado que o fato ou o prognóstico legislativo não corresponder à realidade, a norma dela decorrente deve ser considerada inconstitucional. Entende Kildare Gonçalves Carvalho que "a decisão sobre a

\footnotetext{
41 WAMBIER, 2007, p. 78. Todavia, o simples fato de defender os "interesses da sociedade" já exclui a pretendida neutralidade, pois estará se posicionando em favor de alguém, e não simplesmente opinando acerca do assunto em debate.

${ }^{42}$ Com esse entendimento: MENDES, 2006, p. 480-481.
} 


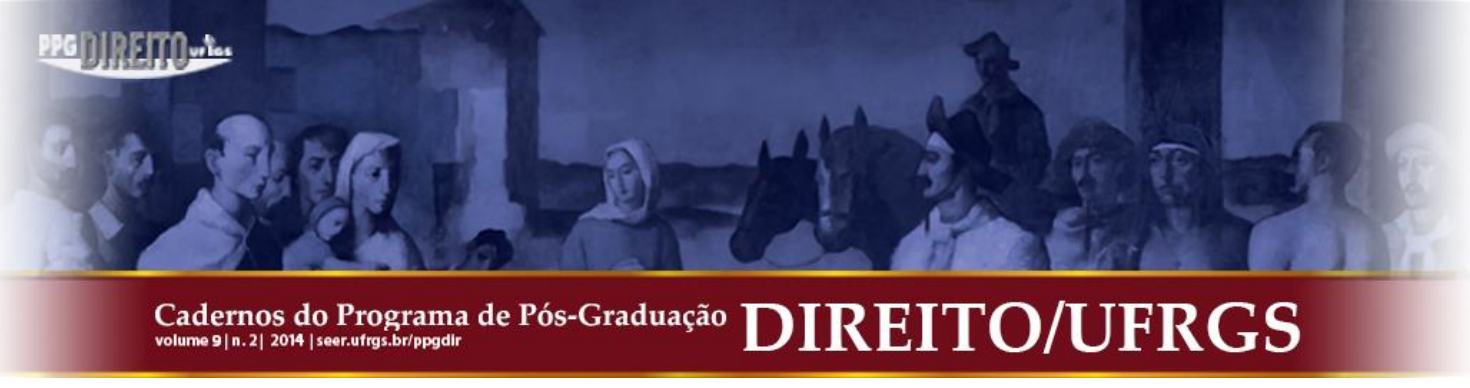

legitimidade de dada lei depende da confirmação de um prognóstico fixado pelo legislador ou de provável verificação de um dado evento" (CARVALHO, 2006, p. 27).

Apesar de ser normalmente confundida e atribuída como espécie de manifestação de amicus curiae, a admissão da análise de fatos no controle concentrado de constitucionalidade tem sua origem na Suprema Corte dos Estados Unidos, com o denominado Brandeis-Brief. Trata-se de uma manifestação formulada pelo advogado Louis Dembitz Brandeis, no caso Muller vs. Oregon, de 1908, na qual reservou apenas duas páginas para tratar de questões jurídicas, e cento e dez laudas para analisar as consequências das longas jornadas de trabalho sobre a mulher ${ }^{43}$. Ou seja, não se limitou a analisar teoricamente a afronta à Constituição, mas a embasou também (e não apenas) com situações de fato que sofrem os efeitos da aplicação da norma.

Apesar de o STF entender que no controle concentrado de constitucionalidade não se admite dilação probatória e o exame dos fatos controversos, acaba por analisar (inclusive revisando) fatos considerados pelo legislador na elaboração das normas. Contudo, não há uma motivação expressa que justifique essa análise de fatos, pois normalmente se utilizam como fundamentos o princípio da igualdade e o postulado da proporcionalidade ${ }^{44}$. Porém, na prática o STF valora os fatos considerados na elaboração das espécies normativas, como na ADI-MC 1910/DF, em que decidiu que o legislador não observou o princípio da isonomia ao instituir prazo decadencial diferenciado para a Fazenda Pública em ação rescisória:

(...) 3. A igualdade das partes é imanente ao procedural due process of law; quando uma das partes é o Estado, a jurisprudência tem transigido com alguns favores legais que, além da vetustez, tem sido reputados não arbitrários por visarem a compensar dificuldades da defesa em juízo das entidades públicas; se, ao contrário, desafiam a medida da razoabilidade ou da proporcionalidade, caracterizam privilégios inconstitucionais: parece ser esse o caso na parte em que a nova medida provisória insiste, quanto ao prazo de decadência da ação rescisória, no favorecimento unilateral das entidades estatais, aparentemente não explicável por diferenças reais entre as partes e que, somadas a outras vantagens processuais da Fazenda Pública, agravam a consequência perversa de retardar sem limites a satisfação do direito do particular já reconhecido em juízo. (...) (ADI-MC 1910/DF, Pleno, rel. Min. Sepúlveda Pertence, j. 22/04/2004, DJ 27/02/2004, p. 19).

\footnotetext{
${ }^{43}$ MENDES, 2005, p. 248.

${ }^{44}$ Nesse sentido: MENDES, 2006, p. 471-472.
} 


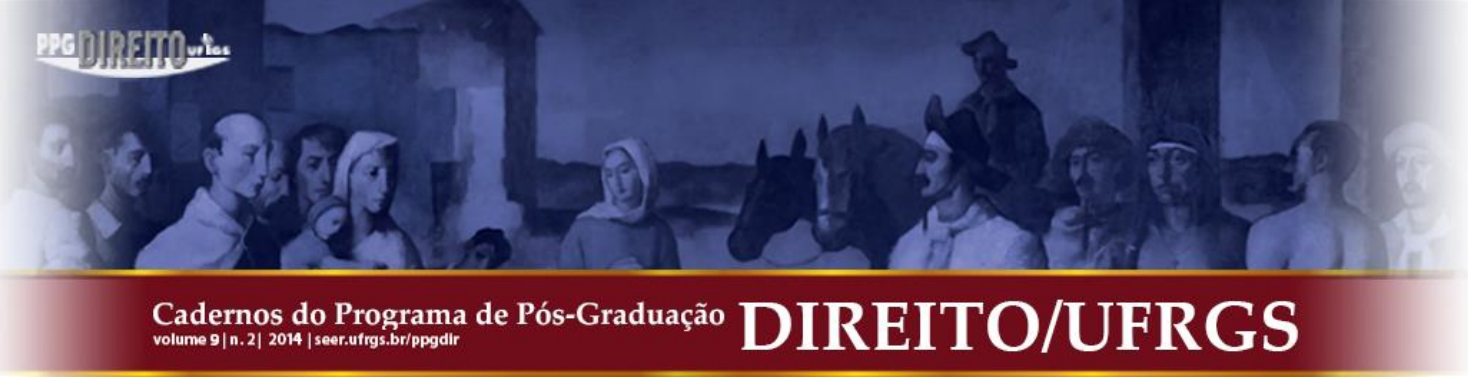

Ainda, na ADI 1276/SP se concluiu que a Assembleia Legislativa do Estado de São Paulo não feriu o princípio da isonomia ao elaborar lei que criou incentivos fiscais a empresas que contratam empregados com idade superior a 40 anos:

Ao instituir incentivos fiscais a empresas que contratam empregados com mais de quarenta anos, a Assembléia Legislativa Paulista usou o caráter extrafiscal que pode ser conferido aos tributos, para estimular conduta por parte do contribuinte, sem violar os princípios da igualdade e da isonomia. (...) (ADI 1276/SP, Pleno, rel. Min. Ellen Gracie, j. 29/08/2002, DJ 29/11/2002, p. 17).

Logo, ainda que implicitamente e com base em motivação diversa, há no controle de constitucionalidade a análise e a revisão dos fatos e prognoses realizadas pelo Legislativo na elaboração das normas ${ }^{45}$.

A Lei $n^{\circ}$ 9.868/99 (que regulamenta o processo da ação direta de inconstitucionalidade e da ação declaratória de constitucionalidade no STF) admite expressamente a análise de fatos e prognoses, por meio do auxílio de pessoas que não são partes no processo. Assim dispõe em seus arts. $9^{\circ}$ e 20 , de semelhante teor:

Art. $9^{\circ}$. Vencidos os prazos do artigo anterior, o relator lançará o relatório, com cópia a todos os Ministros, e pedirá dia para julgamento.

$\S 1^{\circ}$ Em caso de necessidade de esclarecimento de matéria ou circunstância de fato ou de notória insuficiência das informações existentes nos autos, poderá o relator requisitar informações adicionais, designar perito ou comissão de peritos para que emita parecer sobre a questão, ou fixar data para, em audiência pública, ouvir depoimentos de pessoas com experiência e autoridade na matéria.

$\S 2^{\mathrm{o}} \mathrm{O}$ relator poderá, ainda, solicitar informações aos Tribunais Superiores, aos Tribunais federais e aos Tribunais estaduais acerca da aplicação da norma impugnada no âmbito de sua jurisdição.

§ 3ํㅡㄹ As informações, perícias e audiências a que se referem os parágrafos anteriores serão realizadas no prazo de trinta dias, contado da solicitação do relator.

Redação similar possui o art. $6^{\circ}, \S 1^{\circ}$, da Lei $n^{\circ} 9.882 / 99$ (a respeito da arguição de descumprimento de preceito fundamental), usualmente confundido com o amicus curiae:

\footnotetext{
${ }^{45}$ Em decisões monocráticas, o Ministro Gilmar Mendes faz menção expressa aos fatos e prognoses legislativos: “(...) Essa nova realidade pressupõe, além de amplo acesso e participação de sujeitos interessados no sistema de controle de constitucionalidade de normas, a possibilidade efetiva de o Tribunal Constitucional contemplar as diversas perspectivas na apreciação da legitimidade de um determinado ato questionado. Observa-se também que a constatação de que, no processo de controle de constitucionalidade, faz-se, necessária e inevitavelmente, a verificação de fatos e prognoses legislativos, sugere a necessidade de adoção de um modelo procedimental que outorgue ao Tribunal as condições necessárias para proceder a essa aferição. Esse modelo pressupõe não só a possibilidade de o Tribunal se valer de todos os elementos técnicos disponíveis para a apreciação da legitimidade do ato questionado, mas também um amplo direito de participação por parte de terceiros (des)interessados. (...)" (ADI 2441/GO, j. 27/02/2007, DJ 16/03/2007, p. 45).
} 


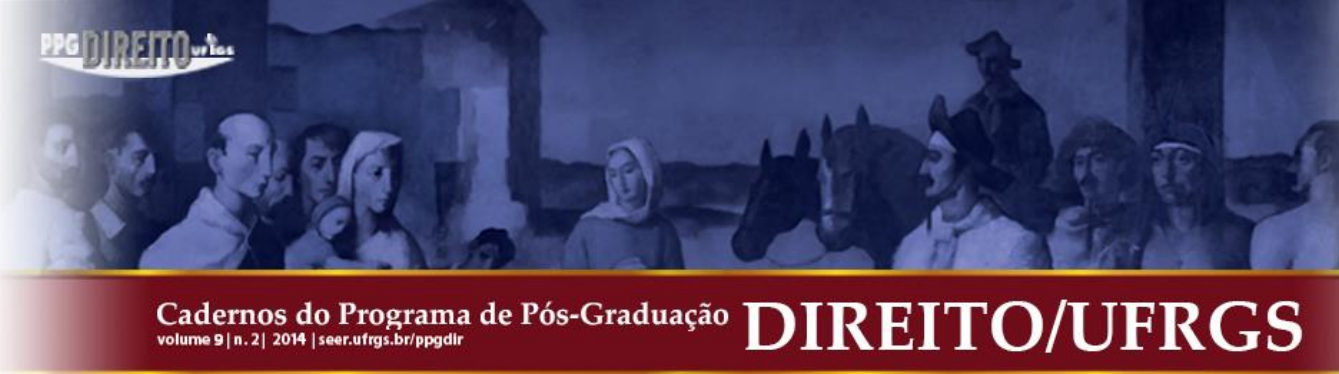

Ministro da Saúde, de médico, cientistas, socióloga, antropóloga, parlamentares, religiosos, entre outros representantes de 25 instituições, com argumentos variados, favoráveis e contrários ao tema objeto do pedido.

A quinta audiência pública realizada pelo STF teve diversas peculiaridades: foi designada pelo então Presidente, Ministro Gilmar Mendes (e não pelo relator do processo), e marcou a extensão de sua utilização para (a) mais de um processo; (b) e relativos ao controle concreto de constitucionalidade. A audiência, ocorrida durante seis dias em abril e maio de 2009, instruiu diversos pedidos de suspensão de segurança, de liminar ou tutela antecipada (incluído o RE 566471/RN) a respeito da concessão de medicamentos ou tratamentos excepcionais não disponibilizados pelo SUS.

No RE 597285 e na ADPF 186, ambas relatadas pelo Min. Ricardo Lewandowski, foi designada audiência pública para os dias 03 a 05 de março de 2010, a fim de debater a constitucionalidade do sistema de cotas nas universidades pública.

Na sequência, durante um intervalo superior a dois anos, o STF não realizou qualquer audiência pública, de março de 2010 a maio de 2012.

De 07 a 14 de maio de 2012 foi promovida audiência pública na ADI 4103, relatada pelo Ministro Luiz Fux, a respeito das normas da Lei no 11.705/2008 (“Lei Seca").

Em 24 e 31 de agosto de 2012, 35 pessoas falaram a respeito dos benefícios e os riscos causados pelo uso industrial do amianto crisotila, proibido pela Lei $\mathrm{n}^{\circ} 12.648 / 2007$, do Estado de São Paulo, e em discussão na ADI 3937 e na ADPF 234, relatadas pelo Ministro Marco Aurélio. Além desses processos, o uso do amianto também está em discussão nas ADI 3357 e 4066.

Mais recentemente, o STF realizou sete audiências públicas no ano de 2013: (a) nos dias 18 e 25 de fevereiro foram instruídas as $\operatorname{ADI} 4679,4747$ e 4756, a respeito da Lei $\mathrm{n}^{\circ}$ 12.482/2011, que regulamenta a televisão por assinatura no Brasil; (b) os efeitos dos campos eletromagnéticos sobre o meio ambiente e a saúde pública foram avaliados por 21 expositores nos dias 6 a 8 de março, para o RE 627189, relatado pelo Ministro Dias Toffoli; (c) no dia 22 de abril, para debater as queimadas nos canaviais em discussão no RE 586224, relatado pelo Ministro Luiz Fux; (d) nos dias 27 e 28 de maio, no RE 641320, relatado pelo Ministro Gilmar Mendes, a respeito da possibilidade de cumprimento da pena em regime aberto nos casos de falta de vagas no sistema prisional; (e) nos dias 17 e 24 de junho, na ADI 4650, 


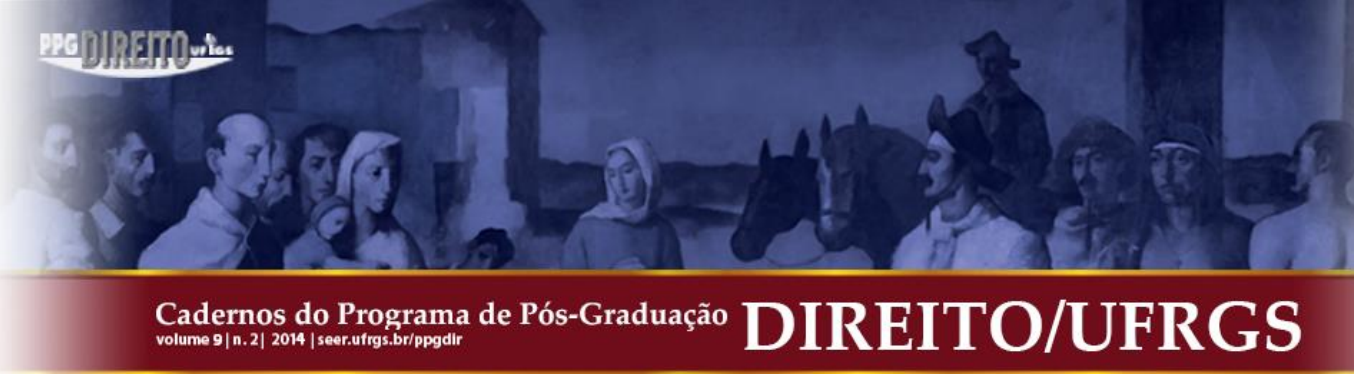

relatada pelo Ministro Luiz Fux, acerca de normas das Leis $n^{\circ}$ 9.096/95 e 9.504/97 a respeito de doações efetuadas por pessoas jurídicas a partidos políticos e a campanhas eleitorais; (f) no dia 21 de novembro de 2013, para debater a (in)compatibilidade das biografias não autorizadas com dispositivos do Código Civil e da Constituição na ADI 4815, relatada pela Ministra Cármen Lúcia; (g) e nos dias 25 e 26 de novembro de 2013, para instruir as ADI 5035 e 5037, relatadas pelo Ministro Marco Aurélio, nas quais se questionam normas do Programa Mais Médicos criado pela Medida Provisória no 621/2013.

Por fim, uma audiência pública foi designada no primeiro trimestre de 2014: no dia 17 de março, 24 participantes manifestaram-se a respeito da Lei $\mathrm{n}^{\circ} 12.853 / 2013$, que trata da gestão coletiva de direitos autorais na Lei $\mathrm{n}^{\circ}$ 9.610/98, para instruir as ADI 5062 e 5065, relatadas pelo Ministro Luiz Fux.

Portanto, das quinze audiências públicas realizadas pelo STF em toda a sua história, quase a metade ocorreu no ano de 2013. Esse dado pode ser interpretado tanto como positivo, por refletir a consolidação do instituto na prática da Corte brasileira, quanto como de forma negativa, por demonstrar um mau uso e a banalização das audiências públicas. Corre-se o risco de que a participação seja reduzida diante do desinteresse causado pela aplicação excessiva do instituto, além de fazer com que, em regra, apenas o relator do processo efetivamente participe das audiências.

\section{Amicus Curiae e Audiências Públicas: Distinções Necessárias}

A incidência da Lei $n^{\circ}$ 9.868/98 leva a outro problema, ainda não padronizado pelo STF (que, ao contrário, ampliou as dúvidas no julgamento do MS 32033): a definição, delimitação e distinção entre amicus curiaee análise de fatos no controle abstrato de constitucionalidade.

Recorda-se que a participação do amicus curiae no controle concentrado de constitucionalidade está prevista no art. $7^{\circ}, \S 2^{\circ}$, da Lei $n^{\circ} 9.868 / 99$, o qual dispõe que "o relator, considerando a relevância da matéria e a representatividade dos postulantes, poderá, por despacho irrecorrível, admitir, observado o prazo fixado no parágrafo anterior, a manifestação de outros órgãos ou entidades".

De outro lado, o controle exercido pelo STF sobre a análise dos fatos realizada pelo legislador (de forma correta ou equivocada), pode resultar na inconstitucionalidade do ato 


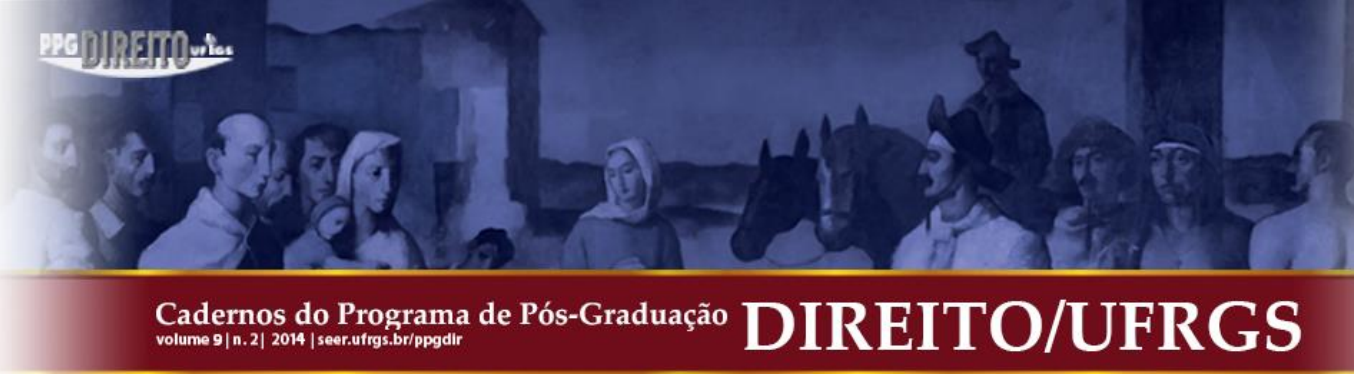

normativo. A Lei no 9.868/99 admite expressamente a análise dos fatos em seus arts. $9^{\circ}$ (ADI) e 20 (ADC), citados acima. Redação semelhante também possui o art. $6^{\circ}, \S 1^{\circ}$, da Lei ${ }^{\circ}$ 9.882/99 (ADPF).

Portanto, não se pode confundir a previsão relativa ao amicus curiae no art. $7^{\circ}, \S 2^{\circ}$, da Lei $n^{\circ} 9.868 / 99$, com a análise de fatos permitida pelos arts. $9^{\circ}$ e 20 da mesma lei, e no art. $6^{\circ}$, $\S 1^{\text {o }}$, da Lei $\mathrm{n}^{\circ} 9.882 / 99$.

As principais diferenças entre os dois institutos do controle abstrato de constitucionalidade são as seguintes: (a) enquanto o amicus curiae é uma pessoa jurídica, na averiguação de fatos são ouvidas apenas as pessoas naturais; (b) a admissão do amicus curiae exige que haja matéria relevante, enquanto a análise fática ocorre quando o assunto não estiver suficiente esclarecido no processo; (c) o ingresso dos amici curiae no feito pode advir de decisão de ofício do relator, ou a pedido daquele, mas a verificação dos fatos somente acontece se houver determinação do relator; (d) de um lado, o amicus curiae pode se manifestar livremente acerca do assunto controvertido, e de outro há uma prévia delimitação dos fatos pelo relator ao requisitar informações de pessoas e tribunais, devendo estes se restringir a responder ou esclarecer as questões fáticas solicitadas ${ }^{46}$.

Contudo, essas diferenças não são rigorosamente observadas pelo STF na prática.

Por exemplo, o aumento da frequência das audiências públicas coincidiu com a falta de rigor nas suas regras: não há mais rigor com a fixação da matéria ou circunstância de fato a ser esclarecida, ou de complemento das informações existentes (conforme determina o $\S 1^{\circ}$ do art. $9^{\circ}$ da Lei $n^{\circ}$ 9.868/99), mas apenas a sustentação oral ampla e irrestrita de pessoas favoráveis e contrárias à constitucionalidade da norma questionada no processo.

Além disso, viu-se que pessoa natural pode ser ouvida em audiência pública, mas não na qualidade de amicus curiae. Contudo, o STF não observou essa distinção em alguns processos, como, por exemplo, no MS 32033. A Corte já possuía precedentes em que

\footnotetext{
${ }^{46}$ A respeito das diferenças: CARDOSO, 2011.
} 


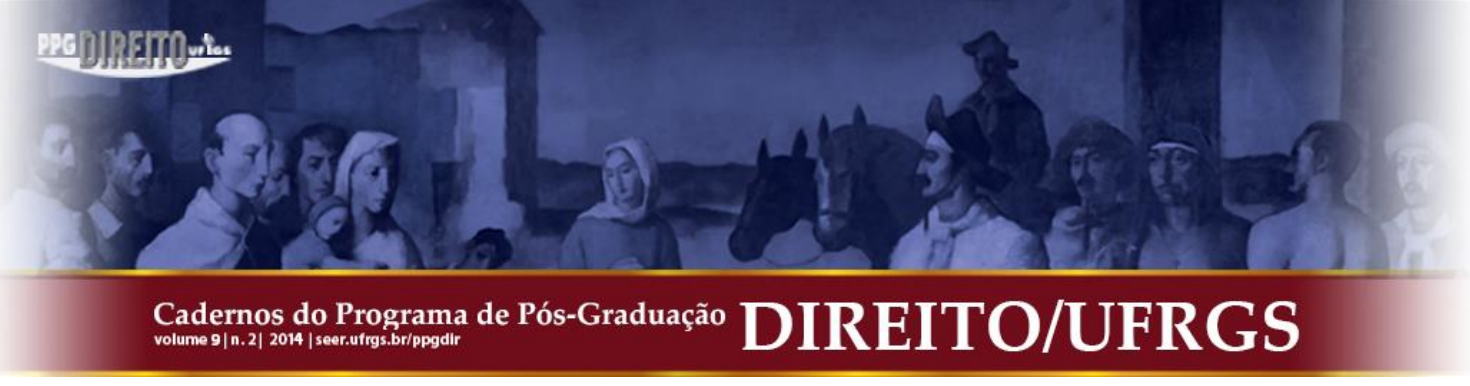

autorizava a manifestação em mandado de segurança ${ }^{47}$, mas neste MS 32033 duas pessoas naturais realizaram sustentação oral como amici curiae $^{48}$.

\section{CONSIDERAÇÕES FINAIS}

Viu-se que não há uma definição ou delimitação legal, tampouco uniformização na atuação dos amici curiae no direito brasileiro, sendo obrigatória em algumas normas, facultativa em outras, e com liberdade de manifestação igualmente diferenciada para cada ato normativo que o regulamenta. Ainda, as normas legais limitam-se a prever a sua manifestação em processos judiciais (com uma hipótese em processo administrativo), em determinadas situações, não existindo no Brasil uma regulamentação ampla. Essa lacuna dá margem a controvérsias, equívocos com outros institutos e limitações indevidas.

Também por esse motivo, na regulamentação do controle de constitucionalidade o amicus curiae não busca somente a correta aplicação da lei e a observância da Constituição (como, por exemplo, a Comissão de Valores Mobiliários e o Conselho Administrativo de Defesa Econômica, nas Leis nº 6.385/76 e 12.529/2011), mas sim representa o interesse da coletividade ou de grupos ou classes sociais, tendo em vista que o papel de defensor da lei é exercido pelo Advogado-Geral da União (art. 102, § $3^{\circ}$, da Constituição ${ }^{49}$. O amicus curiae, no controle abstrato de constitucionalidade brasileiro, constitui uma exceção ao conceito tradicional do instituto, porque se assemelha mais a um amicus causae ou amicus partis, por representar os interesses gerais da coletividade ou de grupos ou classes sociais, assemelhandose a um terceiro com interesse direto na resolução da causa.

\footnotetext{
${ }^{47}$ Por exemplo: MS 29058 MC-AgR/DF, decisão monocrática, rel. Min. Celso de Mello, j. 24/05/2013, DJe 28/05/2013; MS 29426 AgR/DF, decisão monocrática, rel. Min. Celso de Mello, j. 30/04/2013, DJe 03/05/2013; MS 30531/DF, decisão monocrática, rel. Min. Cármen Lúcia, j. 23/04/2012, DJe 04/05/2012.

${ }^{48}$ Esse processo possui outra situação excepcional: à manifestação dos amici curiae em ritos que não o admitam expressamente, como ocorre no mandado de segurança (a Lei $n^{\circ}$ 12.016/2009 não permite e nem proíbe o amigo da Corte). A respeito do assunto: CARDOSO, 2013.

49 “\$ $3^{\circ}$ - Quando o Supremo Tribunal Federal apreciar a inconstitucionalidade, em tese, de norma legal ou ato normativo, citará, previamente, o Advogado-Geral da União, que defenderá o ato ou texto impugnado". O AGU pode deixar de defender o ato quando já houver precedente do STF pela inconstitucionalidade do ato normativo: “(...) O Advogado-Geral da União não está obrigado a defender tese jurídica se sobre ela esta Corte já fixou entendimento pela sua inconstitucionalidade. (...)" (ADI 1616/PE, Pleno, rel. Min. Maurício Corrêa, j. 24/05/2001, DJ 24/08/2001, p. 41).
} 


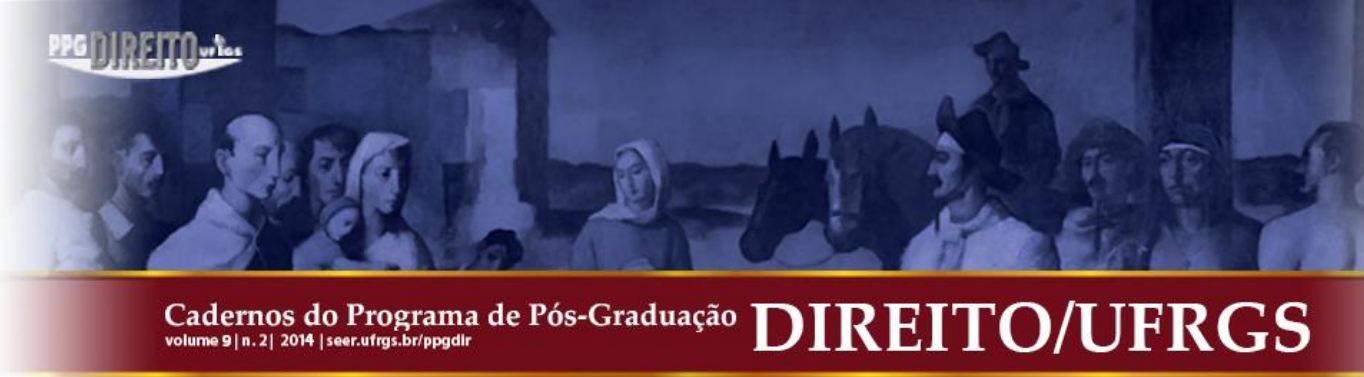

BAZÁN, Victor. El amicus curiae en clave de derecho comparado y su reciente impulso en el derecho argentino. Cuestiones Constitucionales. México, n. 12, p. 29-71, jan./jun. 2005.

BUENO, Cassio Scarpinella. Amicus curiae no processo civil brasileiro: um terceiro enigmático. 3. ed. São Paulo: Saraiva, 2012.

BURDEAU, Georges; HAMON, Francis; TROPER, Michel. Direito constitucional. Barueri: Manole, 2005.

CARDOSO, Oscar Valente. A admissibilidade de pessoa natural como amicus curiae em mandado de segurança no Supremo Tribunal Federal. Revista Dialética de Direito Processual. São Paulo, n. 126, p. 77-84, set. 2013.

CARDOSO, Oscar Valente. Controle abstrato de constitucionalidade: aspectos subjetivos. Rio de Janeiro: Livre Expressão, 2011.

CARDOSO, Oscar Valente. Juizados Especiais da Fazenda Pública (Comentários à Lei $n^{\circ}$ 12.153/2009). São Paulo: Dialética, 2010.

CARVALHO, Kildare Gonçalves. Processo constitucional. Revista do Instituto dos Advogados de Minas Gerais. Belo Horizonte, n. 11, p. 15-43, 2006.

FERREIRA, Joana Cristina Brasil Barbosa. O amicus curiae e a pluralização das ações constitucionais. In: OLIVEIRA, Vallisney de Souza (coord.). Constituição e processo civil. São Paulo: Saraiva, 2008, p. 91-144.

HÄBERLE, Peter. Hermenêutica constitucional: a sociedade aberta dos intérpretes da Constituição: contribuição para a interpretação pluralista e 'procedimental' da Constituição. Porto Alegre: Sergio Antonio Fabris, 1997.

KÖHLER, Ricardo Carlos. Amicus curiae: amigos del tribunal. Buenos Aires: Astrea, 2010.

MACIEL, Adhemar Ferreira. Amicus curiae: um instituto democrático. Revista de Informação Legislativa, Brasília, n. 153, p. 7-10, jan./mar. 2002. 


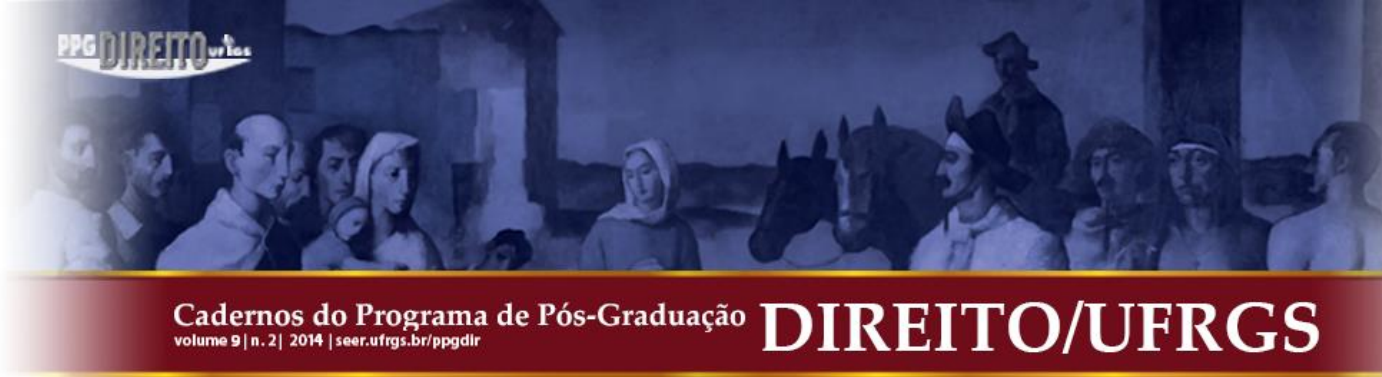

MEDINA, Damares. Amicus curiae; amigo da Corte ou amigo da parte? São Paulo: Saraiva, 2010.

MENDES, Gilmar Ferreira. Direitos fundamentais e controle de constitucionalidade. 3. ed. São Paulo: Saraiva, 2006.

MENDES, Gilmar Ferreira. Jurisdição constitucional. 5. ed. São Paulo: Saraiva, 2005.

MENEZES, Paulo de Tarso Duarte. Aspectos gerais da intervenção do amicus curiae nas ações de controle de constitucionalidade pela via concentrada. Direito Público, Brasília, n. 17, p. 35-51, jul./set. 2007.

MORAES, Guilherme Peña de. Direito constitucional: teoria da Constituição. 3. ed. Rio de Janeiro: Lumen Juris, 2006.

PEREIRA, Milton Luiz. Amicus curiae - intervenção de terceiros. Revista CEJ, Brasília, n. 18, p. 83-86, jul./set. 2002.

SOUZA FILHO, Luciano Marinho de Barros e. Amicus curiae: instituto controvertido e disseminado no ordenamento jurídico brasileiro. Revista jurídica Justilex, Brasília, n. 67, p. 35-37, jul. 2007.

WAMBIER, Tereza Arruda Alvim. Amicus curiae: afinal, quem é ele? Direito e Democracia, Canoas, v. 8, n. 1, p. 76-80. jan./jun. 2007. 